\title{
RELATIONSHIP OF WORKING CAPITAL MANAGEMENT AND PROFITABILITY OF THE FIRMS - AN APPLICATION OF UNIT ROOT AND CO-INTEGRATION TEST ON THE VARIOUS CORPORATE SECTORS OF PAKISTAN STOCK EXCHANGE
}

\author{
Umair Baig \\ Benazir Bhutto Shaheed University (BBSU), Pakistan \\ E-mail: umaiirbaig@gmail.com \\ Salman Sarwat \\ Benazir Bhutto Shaheed University (BBSU), Pakistan \\ E-mail:salman.sarwat@bbsul.edu \\ Danish Iqbal Godil \\ Bahria University, Pakistan \\ E-mail: danishiqbal.bukc@bahria.edu.pk \\ Submission: 3/10/2020 \\ Revision: $3 / 20 / 2020$ \\ Accept: 3/29/2020
}

\section{ABSTRACT}

The main purpose of this research is to find the impact and the long-run relationship of working capital, and profitability in different major sectors of Pakistan stock exchange; for this purpose eight sectors with 95 listed companies selected that can be representative of the Pakistani mindset and practices of the corporate world. For this reason, ROA used as the dependent variable and CCC, CR, QR, WCT ART, APD, ROCE, DR to check the long-run relationship with Firm Performance. OLS is not possible due to the trend in data. In this research unit root test and Penal Co-integration test used for finding the long-run relationship equilibrium. This research paper provides guidelines to corporate practitioners and academia to understand and focus on working capital to improve profitability in the organization. Findings revealed that different sectors have different characteristics of working capital in the long-run equilibrium. This research intends to give future direction for the researcher to develop theories of liquidity and working capital.

Keywords: Liquidity; Working Capital Management; Panel Co-Integration; Panel Unit Root Test; Profitability 
ISSN: 2236-269X

DOI: 10.14807/ijmp.v12i1.1305

\section{INTRODUCTION}

Working capital management is a significant function of corporate finance. Liquidity and profitability directly associated with working capital management. Working capital management administrated the current assets and current liabilities of the corporate (Horne, 2008). Shapiro et al (2019) also mentioned that the management of working capital is an important responsibility of finance manager for multinational firms and its domestic counterpart, both are interested to manage current assets and current liabilities to maintain the profitability of the firm. Working capital management is crucial for financial health and the formal process created an impact on the size of corporate as well (Padachi, 2006).

Eljelly (2004) mentioned that effective working capital management has the capacity to manage current assets and current liabilities in a way to manage current assets on current liabilities and the firm must be in the position to easily pay of all the uncertain obligations whenever it urgently required. Horne and Wachowicz (2000) highlighted the significance of working capital management and realized it as an essential tool for corporate finance. Moreover, claimed that it is very important due to several reasons. For instance, manufacturing firms usually maintained current assets at least half of the total assets of the firm, distributions companies maintain even more current assets as compared to current liabilities and a number of the industry having various strategies to maintained financial performance.

Eljelly (2004), also emphasized that effective working capital management deals with proper planning and control all the concerned matters of current assets and current liabilities in a such a way to handle all upcoming challenges of operational activities. Horne (2008) maintained that corporate having the excessive current assets perform much better as compared to those firms who are unable to manage the administered issues of current assets and current liabilities. Moreover, Kumar (2011) highlighted that working capital is a core responsibility and essential part of investment decision to face the challenges of short term investment and short term financing of the corporate. Therefore, the novelty of this current study is to find long term relationships.

However, past researchers have developed consensus that working capital management is not as simple as the theory suggested. Somehow, it is a very complex decision in short term perspectives. The prime goal of the finance manager is to maintain the profitability of the firm, although liquidity and profitability are the inverses of each other. Therefore, a firm focuses on increasing profitability in the short and long term perspective to developed strategies regarding 
INDEPENDENT JOURNAL OF MANAGEMENT \& PRODUCTION (IJM\&P)

http://www.ijmp.jor.br

v. 12, n. 1, January-February 2021

ISSN: 2236-269X

DOI: 10.14807/ijmp.v12i1.1305

working capital management. (Banos-Caballero et al. 2011; Lazaridis \& Tryfonidis 2006; Deloof 2003; Shin \& Soenen, 1998).

Smith (1980) highlighted that working capital comprised of the management of cash, inventory, receivables and payable and directly and indirectly influences the liquidity, profitability of the firm. Sharma and Kumar (2011) also highlighted that working capital is a core responsibility and essential part of investment decision to face the challenges of short term investment and short term financing of the corporate. Therefore, the novelty of this study is to find long term relationships. Horne (2012) mentioned that working capital policy, directly and indirectly, created an impact on liquidity, risk, and profitability and emphasized that there are three forms of working capital policy contemporaneous. Conservative, Trade-off and Hedging and these policies formed a huge impact for instance; in conservatives' policy maintain high liquidity, low risk and low profitability of the firm. In the case of trade-off policy; liquidity, risk, and profitability of the firm occurred as average. Moreover, in the case of the Hedging policy, Liquidity of the firm reduced. However, risk and profitability increase as before.

Many researchers agreed that working capital management as short term functions of corporate finance is essential for all kinds of firms. Firm size, country, sectors, type of industry, etc. (Gill, Biger \& Mathur, 2010; Lazaridis \& Tryfonidis, 2006; Deloof, 2003; Shin \& Soenen, 1998). However, past researchers argued that literature of corporate finance was concentrated and given intense time on long term decision criteria and ignored the short term decisions impact on long term perspectives (Juan, 2007).

This current study focuses on a ground-breaking approach, merge operational and financial skills and an all encircling view of the company's operations that will help in discovering and executing strategies that create short term cash. Furthermore, if the issue of liquidity and working capital can be tackled on a corporate-wide basis it will benefit the firm. Therefore, the current study designed and analyse the Relationship of Working Capital Management and Profitability of the firms - An Application of Unit root and Co-Integration test on the various corporate sectors of Pakistan Stock Exchange. For this reason, ROA used as the proxy of profitability and Cash Conversion Cycle, Current Ratio, Quick Ratio, Working Capital Turnover, Account Receivable Turnover, Account Payable Turnover, Return On Capital Employed, Debt Ratio to check the long-run relationship with working capital management. OLS is not possible due to the trend in data. Hence, in this study, the unit root test and Penal Co-integration test used for finding the long-run relationship equilibrium. 
DOI: 10.14807/ijmp.v12i1.1305

The remaining paper consists of four major sections. Section-2 explore the Literature review, Section-03 is related to methodology, Section-04 dealt with Research Results and Analysis and section-05 composed on conclusion.

\section{LITERATURE REVIEW}

Sagan (1955) was the first researcher of this domain and found the relationship between working capital and firm performance and argued that the working capital is necessary for all types of corporates to manage firm performance. In the contemporary world, it is necessary to evaluate country to country, level of influence of working capital on firm performance moderated because of the passage of time the situations had changed. Therefore, past researchers have a different opinion on different time periods and different parts of the world. Therefore, in the section, past researchers' findings provide a framework for conducting new horizons of working capital management.

Working capital management (WCM) is crucial as it fervently impacts on corporate performance. WCM is an essential concept to make liquidity and profitability differentiation among corporations, is to involve the decision and combination of short term financing and short term resources. All aspects of working capital, which involve cash, marketable securities inventory management play a significant role in any organization. Mudanya and Muturi, (2018) described working capital as a tool that manages current assets and current liabilities. Moreover, working capital management is an essential function of investment decisions that are properly implemented to increase the worth of shareholders. However, Igbekoyi (2017) demonstrated that working capital management is dependent on profitability and put a significant impact on the firm's performance. The objective of working capital is to create a realization about to retain the reasonable cash flow in the normal and ideal condition of a firm which minimizes the risk to pay immediate commitments. However, unnecessary investment should be taken into consideration in working capital management. Meanwhile, working capital investment minimizes to reduce the chances of risk which influences liquidity. Working capital management puts the adversely impact on regular operations if the amount of WCM is insufficient. It is helpful for the decision-maker to provide an example of risk-return.

Samiloglu (2016) demonstrates that the working capital management connects to control the payable, inventories, account receivable and cash. It is a necessity daily for business, the firm requires a regular amount of cash for paying bills, accounts payable, for covering the unexpected cost and purchase materials for a daily basis. However, Edem (2017) believed that 
DOI: 10.14807/ijmp.v12i1.1305

WCM is also known by cash conversion cycling, this is the weight of time that turn the present assets and present liabilities in the cash. Firm's goal to reduce their WC by collecting accounts receivable quickly and sometimes by stretching the accounts payable. The importance of WCM is incontestable and whether its element they are managed whole or individual. This management is important to order the organization to manage the cash flow effectively and continue the operation.

Mathuva (2010) used Pearson and Spearman's correlations, the Pooled Ordinary Least Square (OLS), and the fixed effects regression models to conduct data analysis. He deliberated the pressure of working capital management workings upon corporate profitability by using a sample of 30 companies listed on the Nairobi Stock Exchange (NSE) from 1993 to 2008. His study concluded that there is an extremely important negative relationship between the accounts collection period and profitability. Given the relationship between profitability and the inventory conversion period or the average payment period, the consequences were positive and significant.

Gill et al. (2010) observed the relations between working capital management and profitability. A sample of 88 American companies listed on the New York Stock Exchange for a period of 3 years from 2005 to 2007 was selected. They too constitute a remarkable relationship between working capital and profitability. Zariyawati et al. (2009) scrutinized the relationship between working capital management and corporate profitability. Cash Conversion Cycle was used as a measure for working capital management and the study was based on panel data for 1,628 companies for the period 1996- 2006 from six different economic sectors listed on Bursa Malaysia.

The coefficient results of the Pooled OLS regression analysis provided a strong negative significant relationship between Cash Conversion Cycle and corporate profitability. This reveals that reducing the cash conversion period results in enlarged profitability. Therefore, company directors are thought to work on shortening the cash conversion cycle to the best possible stage is achieved. Nobanee and AlHajjar (2009) Examined a sample of 2,123 Japanese non-financial companies listed on the Tokyo Stock Exchange for the period 1990-2004 and accomplished that company managers can augment profitability by limiting the cash conversion cycle, the receivables collection period and the inventory conversion period. The outcome also recommended that lengthening the payables delay period might enlarge profitability. Though, managers should be careful as lengthening the payables deferment period could harm the company's credit standing and damage its profitability in the long run. 
DOI: 10.14807/ijmp.v12i1.1305

Nazir and Afza (2009) highlighted an effort in order to examine the long-established relationship between working capital management strategy and a firm's profitability for a sample of 204 non-financial firms listed in the Karachi Stock Exchange (KSE) for the period 1998-2005. The study originated important dissimilarities among their working capital requirements and financial policies across dissimilar businesses. Furthermore, regression results originated a negative relationship between the profitability of firms and the degree of violence of working capital investment and financing strategy. They recommended that managers could pleat worth if they withdraw along with a traditional approach towards working capital investment and working capital funding policies.

Falope and Ajilore (2009) Using a sample of 50 Nigerian companies quoted nonfinancial firms for the period 1996 -2005, highlighted an important negative relationship between net operating profitability and the average collection period, inventory turnover in days, average payment period and cash conversion cycles for a sample of 50 Nigerian firms listed on the Nigerian Stock Exchange. Moreover, they figured no major variations in the effects of working capital management between large and small firms. Samiloglu and Demirgunes (2008) elucidated that the possessions of working capital management upon corporate performance have been the canter of a considerable quantity of theoretical and experiential research for numerous years and in diverse surroundings. A traditional approach to the relations between cash conversion cycle and profitability posits that relatively long cash conversion periods tend to decrease profitability.

It means that reducing working capital investment would absolutely persuade the companies' profitability by dropping the proportion of current assets in total assets. The majority of the studies in this area demonstrate that companies can improve their profitability by shortening the cash conversion cycle as they originate a strong negative relationship between these two variables. A variety of consequences were attained when it comes to the association between diverse components of the Cash Conversion Cycle and corporate profitability.

\section{METHODOLOGY}

The current study was quantitative in nature. In this research, developed eight categories of thirteen major sectors of Pakistan stock exchange with 95 listed companies; calculated all concerning financial ratios related to working capital management which exclusively covered 
DOI: 10.14807/ijmp.v12i1.1305

liquidity parameter and long-run variable is also included to measure the long term effect with the profitability of listed companies for the period of 2009 to 2018.

This research is to be the largest and to be the first-ever in Pakistan, where the relationship and impact of liquidity and working capital management on profitability is tested by unit root test and penal Co-integration test. The idea of co-integration arose out of the concern about spurious or nonsense regressions in time series. Specifying a relation in terms of levels of the economic variables, say $y_{t}=\alpha+\beta x_{t}+u_{t}$, often produces empirical results in which the $\mathrm{R}^{2}$ is quite high, but the Durbin-Watson statistic is quite low. This happens because economic time series are dominated by smooth, long term trends. That is, the variables behave individually as non-stationary random walks. In a model that includes two such variables, it is possible to choose coefficients that make ${ }^{y_{t}-\hat{\alpha}-\hat{\beta} x_{t}}$ appear to be stationary. But such an empirical result tells us little of the short-run relationship between $\mathrm{y}_{\mathrm{t}}$ and $\mathrm{x}_{\mathrm{t}}$. In fact, if the two series are both I (1) then we will often reject the hypothesis of no relationship between them even when none exists. The following are the eight unique sectors of Pakistan stock exchange which were evaluated with the help of the unit root test and Co-integration test.

Table 1 : These are the 8 sectors which consist of 95 listed companies of Pakistan

\begin{tabular}{llc}
\hline S. No & Sectors & No. of Companies \\
\hline 1 & Automobile Sector & 7 \\
2 & Cable \& Electrical Goods & 5 \\
3 & Cement Sector Pharmaceuticals & 22 \\
4 & Food \& Personal Care & 14 \\
5 & Pharmaceuticals & 19 \\
6 & Oil \& Gas Sector & 8 \\
7 & Technology and Communication & 8 \\
8 & Textile & 12 \\
& Total & $\mathbf{9 5}$ \\
\hline
\end{tabular}

\subsection{The hypothesis of the study.}

The hypothesis of this study is as follows:

- H1: There is no relationship between efficient working capital management and profitability of Pakistani firms.

\subsection{Defining Different Variables}

To observe the fact of the impact and relationship of working capital management on the firm's profitability, Return on Assets (ROA) will be used as a proxy of profitability. As far as the working capital variable are concerned; current ratio, quick ratio, accounts receivable 
INDEPENDENT JOURNAL OF MANAGEMENT \& PRODUCTION (IJM\&P)

http://www.ijmp.jor.br

v. 12, n. 1, January-February 2021

ISSN: 2236-269X

DOI: 10.14807/ijmp.v12i1.1305

turnover, inventory turnover, account payable turnover, working capital turnover, return on

capital employed and to measure long term issues Debt ratio used as a proxy.

Table 2: Defining different Variables

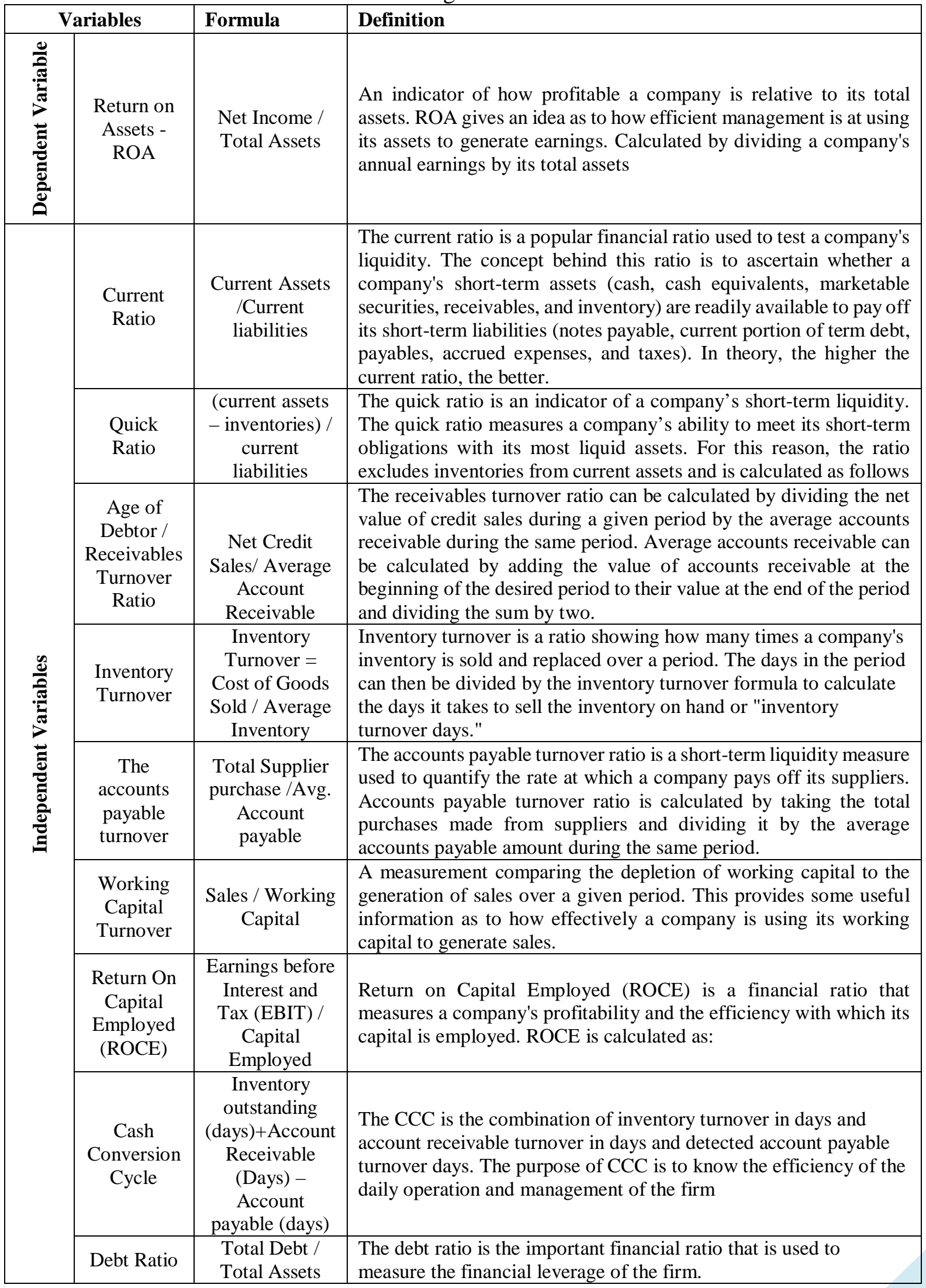


DOI: 10.14807/ijmp.v12i1.1305

\section{RESEARCH RESULTS AND ANALYSIS}

\subsection{The panel Unit Root Test Findings}

The analysis starts by testing the stationary of all variables in the study to determine the order of integration of the 9 variables. In this research Philips-Perron test based on equation one (1), the maximum leg length used in this research is 1 . The Philips-Perron unit root test explains that the null hypothesis that each time series contains a unit root, and the alternative hypotheses that each time series is stationary

$$
\begin{aligned}
& \mathrm{H}_{0}: \rho_{i}=\rho=0 \text { for all } i \\
& \mathrm{H}_{1}: \rho_{1}=\rho_{2}=\cdots=\rho<0 \text { for all } i
\end{aligned}
$$

The tables in Appendix-1 indicate eight sectors for the data to be non-stationary at the level and found trends in the data. After taking the first difference of the data it becomes stationary. When data is non-stationary at the level and becomes stationary at first difference, the result of the ordinary least square method becomes spurious. Therefore, the long-run equilibrium relations among the variables are drawn. Hence, now using the Johansen cointegration test for further process. The condition of the Johansen cointegration test is that all the variables are integrated at order.

\subsection{The Panel of Co-Integration Test Results}

The results indicate to reject the null hypothesis of no co-integration between variables in the two models. There is a long-run relationship between profitability, working capital management, size of the firm and debt ratio. Also, there is a long-run relationship between profitability, liquidity and the size of the firm where those variables are moving together in the long run. In this portion, eight sectors of Pakistan are explained one by one.

\subsubsection{Automobile Sector of Pakistan}

[Insert Exhibit 1 here]

The Exhibit-1 shows that the co-integration test shows that at most one co-integration equation in the system.

Table 3 shows the clear picture of the automobile sector of Pakistan, where all concerned variables are significant except the current ratio in the long run. Table- 1 also explains the relationship status of concerned variables of liquidity, working capital, and 
INDEPENDENT JOURNAL OF MANAGEMENT \& PRODUCTION (IJM\&P)

http://www.ijmp.jor.br

v. 12, n. 1, January-February 2021

ISSN: 2236-269X

DOI: 10.14807/ijmp.v12i1.1305

profitability. CCC, Inventory, A/c payable turnover, ROCE, and Debt ratio is positively related to the return on assets.

Table 3: Automobile Sector

\begin{tabular}{lccccc}
\hline Variables & Coefficient & Standard Error & T statistics & Status & Relationship \\
\hline Cash conversion cycle & 0.084979 & 0.01065 & 7.979249 & Significant & Positive \\
Current Ratio & 0.17049 & 0.58751 & 0.290191 & Insignificant & - \\
Account Receivable & -0.17049 & 0.02842 & -5.99894 & Significant & Negative \\
Turnover (days) & 0.096088 & 0.0063 & 15.25206 & Significant & Positive \\
Inv. Turnover times & -3.452084 & 0.88169 & -3.9153 & Significant & Negative \\
Quick ratio & -0.170468 & 0.01255 & -13.5831 & Significant & Negative \\
Working capital turnover & 0.222459 & 0.01771 & 12.56121 & Significant & Positive \\
ROCE & 13.73838 & 1.28953 & 10.65379 & Significant & Positive \\
Debt ratio & 0.128047 & 0.01334 & 9.598726 & Significant & Positive \\
A/c payable Turnover & & &
\end{tabular}

It means credit sales are performing an important role in this sector. When credit sales increase then similarly account receivable and inventory turnover increase in this sector, delays in account payable turnover will be the reason for improving CCC. CCC will be caused to improve return on assets of the company, although the current ratio is insignificant in this sector in the long-run equilibrium. Working capital and quick ratio are negatively related to ROA. It will be guidelines for this sector to manage and concentrate on liquidity and working capital issues to increase profitability position in the sector. Moreover, it may be very much sure that this situation will be different from other sectors of Pakistan.

\subsubsection{Cable and Electric Goods Sector of Pakistan}

[Insert Exhibit 2 here]

Exhibit-2 shows that the co-integration test shows that at most one co-integration equation in the system.

Table 4: Cable and Electric Goods Sector of Pakistan

\begin{tabular}{lccccc}
\hline Variables & Coefficient & Standard Error & T statistics & Status & Relationship \\
\hline Cash conversion cycle & -0.024903 & 0.00508 & 4.902165354 & Significant & Negative \\
Current Ratio & -11.8495 & 3.00154 & 3.947806793 & Significant & Negative \\
Account Receivable & -0.129377 & 0.0107 & & & Negative \\
Turnover (days) & -5.712777 & 0.02555 & 223.5920548 & Significant & Negative \\
Inv. Turnover times & -0.149583 & 3.38134 & 0.044237787 & & Negative \\
Quick ratio & -0.345737 & 0.02698 & 12.81456635 & Significant & Negative \\
Working capital turnover & 20.606845 & 0.03957 & 520.769396 & Significant & Positive \\
ROCE & 20.60845 & 5.87341 & 3.508770884 & Significant & Positive \\
Debt ratio & 0.016865 & 0.01217 & 1.385784717 & Significant & Positive \\
A/c payable Turnover & & & & &
\end{tabular}

Table 4 indicates a clear picture of Cable and Electric Goods sector of Pakistan, all the concerned variable are significant to the ROA, where cash conversion cycle to working capital turnover is negatively related to Profitability, it means in this sector liquidity is negatively 
DOI: 10.14807/ijmp.v12i1.1305

related to return on assets in long-run equilibrium. On the other hand, ROCE and Debt ratio and account payable turnover are positively related in the long-run equilibrium.

This is an amazing finding of the cable and electric goods sector of Pakistan, which highlights sector differences. In short, findings reveal that the previous sector of Pakistan i.e. the automobile sector discussed earlier are comparatively different as to the cable and electric goods sector of Pakistan.

\subsubsection{Cement Sector of Pakistan}

[Insert Exhibit 3 about here]

Exhibit-3 shows that the co-integration test shows that at most one co-integration equation in the system.

Table 5: Cement Sector

\begin{tabular}{lccccc}
\hline Variables & Coefficient & Standard Error & T statistics & Status & Relationship \\
\hline Cash conversion cycle & 3.076332 & 0.58306 & 5.276184269 & Significant & Positive \\
Current Ratio & -77.39863 & 31.9147 & -2.425171786 & Significant & Negative \\
Account Receivable & -3.7463 & 0.61946 & -6.047686695 & Significant & Negative \\
Turnover (days) & 3.245587 & 0.85083 & 3.81461279 & Significant & Positive \\
Inv. Turnover times & 58.61708 & 28.623 & 2.047901338 & Significant & Positive \\
Quick ratio & -0.837278 & 0.21448 & -3.903757926 & Significant & Negative \\
Working capital & 3.155409 & 0.46392 & 6.801623125 & Significant & Positive \\
turnover & -251.8918 & 69.5029 & -3.624191221 & Significant & Negative \\
ROCE & -3.162266 & 0.53325 & -5.93017534 & Significant & Negative \\
Debt ratio & & & & & \\
A/c payable Turnover & & & & \\
\hline
\end{tabular}

This table 5 shows the position of the cement sector of Pakistan which consists of 22 listed companies. This sector is a very strong manufacturing sector and has a contribution to the industrial sector of the GDP of the country. Table-5 shows the position of liquidity and working capital position with profitability. Interesting findings revealed that all concerned variables are significant with ROA Table 5 also explain the long-run relationship with the profitability.

The table 5 explains that liquidity and working capital management is negatively related to profitability in this sector, except CCC and ROCE is positively related to the ROA. The expert should be concentrating on this issue where liquidity is negatively related in ROA but CCC is positively associated with ROA.

\subsubsection{Food \& Personal Care}

[Insert Exhibit 4 here] 
INDEPENDENT JOURNAL OF MANAGEMENT \& PRODUCTION (IJM\&P)

http://www.ijmp.jor.br

v. 12, n. 1, January-February 2021

ISSN: 2236-269X

DOI: 10.14807/ijmp.v12i1.1305

The Exhibit-4 after conducting a co-integration test indicates at most one cointegration equation in the system.

Table 6: Food \& Personal Care

\begin{tabular}{lccccc}
\hline Variables & Coefficient & Standard Error & T statistics & Status & Relationship \\
\hline Cash conversion cycle & -1.283151 & 0.17489 & -7.3369 & Significant & Negative \\
Current Ratio & -106.9962 & 17.6932 & -6.04731 & Significant & Negative \\
Account Receivable & 1.612832 & 0.63900 & & Significant & Positive \\
Turnover (days) & & & 2.523994 & & \\
Inv. Turnover times & -25.04660 & 4.59450 & -5.45143 & Significant & Negative \\
Quick ratio & 164.9764 & 22.6525 & 7.282922 & Significant & Positive \\
Working capital turnover & 0.005356 & 0.00307 & 1.744625 & Insignificant & -- \\
ROCE & 0.975612 & 0.60139 & 1.622262 & Insignificant & -- \\
Debt ratio & -38.51294 & 15.5821 & -7.3369 & Significant & Negative \\
A/c payable Turnover & -2.531618 & 0.39228 & -6.04731 & Significant & Negative \\
\hline
\end{tabular}

The table 6 shows the food and personal care sector of Pakistan which consists of 14 companies and this sector is one of the largest sections of Pakistan. All concerned variables are significant except working capital turnover and ROCE in the food and personal care sector of Pakistan.

Liquidity ratios have a negative long-run equilibrium relationship with ROA. Interestingly account payable turnover and debt ratio have a negative relation too with ROA in the food and personal care sector of Pakistan in the long-run equilibrium. Hence, these sectors firms should be careful regarding designing the capital structure of the firms in long-run perspectives.

\subsubsection{Glass \& Ceramics and Paper \& board}

[Insert Exhibit 5 about here]

The Exhibit-5 shows that the co-integration test shows that at most one co-integration equation in the system.

Table 7: Pharmaceuticals

\begin{tabular}{|c|c|c|c|c|c|}
\hline Variables & Coefficient & Standard Error & T statistics & Status & Relationship \\
\hline Cash conversion cycle & -0.229357 & 0.04012 & -5.71677 & Significant & Negative \\
\hline Current Ratio & 26.82231 & 5.75266 & 4.662593 & Significant & Positive \\
\hline \multicolumn{6}{|l|}{ Account Receivable } \\
\hline Turnover (days) & 0.264747 & 0.07368 & 3.5932 & Significant & Positive \\
\hline Inv. Turnover times & -1.250992 & 0.14954 & -8.3656 & Significant & Negative \\
\hline Quick ratio & -5.178395 & 7.99048 & -0.64807 & Insignificant & --- \\
\hline Working capital turnover & 0.034078 & 0.05804 & 0.587147 & Insignificant & --- \\
\hline ROCE & 0.146145 & 0.19233 & 0.759866 & Insignificant & --- \\
\hline Debt ratio & 58.40523 & 16.2035 & 5.71677 & Significant & Positive \\
\hline $\mathrm{A} / \mathrm{c}$ payable Turnover & 0.099436 & 0.04503 & 4.662593 & Significant & Positive \\
\hline
\end{tabular}

The table 7 is showing the status of two sectors Glass \& Ceramics and Paper \& board and supports that the position of current ratio and Account receivable turnover (days) means 
DOI: 10.14807/ijmp.v12i1.1305

important indicators of liquidity have a positive long-run equilibrium relation with ROA. Concerned variables affect ROA except for Quick ratio, Working capital turnover, and ROCE is insignificant with the ROA. Findings revealed the managing working capital could be beneficial for a long term perspective for designing the optimal capital structure. This sector is insignificant as far as ROCE is concerned in long term equilibrium is concerned. Although, Inventory turnover in days and CCC is negatively related to the ROA in the long-run equilibrium. Therefore, the policymaker of these sectors must concentrate on results and prepare the policy accordingly.

\subsubsection{Oil and Gas sector of Pakistan}

[Insert Exhibit 6 about here]

Exhibit-6 after conducting the co-integration test shows at most one co-integration equation in the system.

Table 8: Oil and Gas

\begin{tabular}{lccccc}
\hline Variables & Coefficient & Standard Error & T statistics & Status & Relationship \\
\hline Cash conversion cycle & -0.061672 & 0.00608 & -10.14342 & Significant & Negative \\
Current Ratio & -125.2148 & 5.42532 & -23.07971 & Significant & Negative \\
Account Receivable & 0.303425 & 0.04013 & & Significant & \\
Turnover (days) & & & 7.56105 & & \\
Inv. Turnover times & -0.211940 & 0.00772 & -27.45337 & Significant & Negative \\
Quick ratio & -93.59218 & 4.59140 & -20.3842 & Significant & Negative \\
Working capital turnover & -0.247336 & 0.01213 & -20.39044 & Significant & Negative \\
ROCE & 0.377373 & 0.02686 & 14.0496 & Significant & Positive \\
Debt ratio & 37.89794 & 14.1406 & 10.14342 & Significant & Positive \\
A/c payable Turnover & -0.145866 & 0.01305 & -23.07971 & Significant & Negative \\
\hline
\end{tabular}

The table 8 is indicated the true picture of working capital, and profitability in the sector of oil and Gas of Pakistan, where all concerned variables are significant with ROA in the oil and gas sector of Pakistan which shows that all impact on ROA. However, Liquidity and working capital are negatively related to the return on assets, as liquidity reduces the profitability increases and as working capital reduces then profitability also increases in the long-run equilibrium. Debt ratio is positively related to ROA, which depicted that debt increases in the oil and gas sector then profitability will defiantly increase in long-run equilibrium.

\subsubsection{Technology and Communication}

[Insert Exhibit 7 about here] 
INDEPENDENT JOURNAL OF MANAGEMENT \& PRODUCTION (IJM\&P)

http://www.ijmp.jor.br

v. 12, n. 1, January-February 2021

ISSN: 2236-269X

DOI: 10.14807/ijmp.v12i1.1305

Exhibit-7 after conducting integration test shows at most one co-integration equation in the system.

Table 9: Technology and Communication

\begin{tabular}{lccccc}
\hline Variables & Coefficient & Standard Error & T-Statistics & Status & Relationship \\
\hline Cash conversion cycle & -0.693148 & 0.03165 & -21.9004 & Significant & Negative \\
Current Ratio & -9.987897 & 2.27843 & -4.38368 & Significant & Negative \\
Account Receivable & 0.414003 & 0.02805 & & Significant & Positive \\
Turnover (days) & & & 14.75947 & & \\
Inv. Turnover times & -0.007641 & 0.00103 & -7.41845 & Significant & Negative \\
Quick ratio & -23.11445 & 2.71859 & -8.50237 & Significant & Negative \\
Working capital turnover & -3.383820 & 0.15450 & -21.90175 & Significant & Positive \\
ROCE & 0.484792 & 0.02810 & 17.25238 & Significant & Positive \\
Debt ratio & 110.9648 & 2.59530 & -21.9004 & Significant & Negative \\
A/c payable Turnover & 0.703889 & 0.03136 & -4.38368 & Significant & Positive \\
\hline
\end{tabular}

The table 9 shows the liquidity, working capital and profitability situation of the technology and communication sector of Pakistan. Table 9 shows that liquidity and working capital is significant for the profitability in long-run equilibrium, it means all variable effect on ROA. In this sector, liquidity is negatively related to the ROA in the long-run equilibrium but working capital turnover and account receivable turnover are positively related to return on assets. The financial Manager of this industry should focus on the difficult combination of relationship with ROA. Decision-makers must manage the working capital to secure the fundamental interest of the industry, however, multiple dimensions exist in this sector due to various factors of the country (i.e.) economy, political, etc.

\subsubsection{Textile}

[Insert Exhibit 8 about here]

Exhibit-8 after conducting the co-integration test shows at most one co-integration equation in the system.

Table 10: Textile

\begin{tabular}{lllrrr}
\hline Variables & Coefficient & Standard Error & T statistics & \multicolumn{1}{c}{ Status } & \multicolumn{1}{c}{ Relationship } \\
\hline Cash conversion cycle & -0.178455 & 0.14903 & -1.19744 & Insignificant & -- \\
Current Ratio & -82.35920 & 8.33985 & -9.875381 & Significant & Negative \\
Account Receivable & 0.300263 & 0.16488 & & Insignificant & - \\
Turnover (days) & & & 1.8211 & & \\
Inv. Turnover times & -1.141019 & 1.94294 & -0.58726 & Insignificant & -- \\
Quick ratio & -78.79853 & 11.3617 & -6.93545 & Significant & Negative \\
Working capital turnover & -0.000690 & 0.00448 & -0.15402 & Insignificant & -- \\
ROCE & 0.465399 & 0.23291 & 1.998192 & Insignificant & - \\
Debt ratio & 88.84772 & 25.7164 & -1.19744 & Insignificant & Negative \\
A/c payable Turnover & -0.070962 & 0.14824 & 9.875381 & Significant & Negative \\
\hline
\end{tabular}

The table 10 shows a very interesting finding of the textile sector of Pakistan; wherein this sector liquidity and working capital are negative related to ROA in the long-run equilibrium 
DOI: 10.14807/ijmp.v12i1.1305

whereas Cash conversion cycle, account receivable turnover, inventory turnover, ROCE, are insignificant in long-run equilibrium. This is the first sector in our available sectors where most of the variables are insignificant in the long-run equilibrium. This is one of the largest sectors of Pakistan listed companies of PSX-100 index. Due to several economic policy changes and adoption of a new model by the govt.

Severe impact coming on the textile sector of Pakistan. Research findings are near to the reality of Pakistan. Therefore, all decision-makers from the textile sector are advised to focus on sector abrupt changes due to several prevailing issues of Pakistan's economy. Further operational research required for finding the reasons for the insignificance of mostly variables in this sector.

\section{CONCLUSION}

The reason for this huge and comprehensive research is to find the relationships of working capital management with firm performance amongst multiple sectors in Pakistan. This research was designed with the goal of investigating the relationship between working capital with the firm's profitability and so after empirical analysis with the help of the Unit root and Penal co-integration test, many imperative findings revealed that working capital is significant for profitability in long term equilibrium. In the first step, the unit root test was applied to check the data trend and for all variables. This study stated that all variables except financial ratios were stationary at first difference, thus 9 variables were included in the panel co-integration test. Moreover, the penal Co-integration test discovered that there was a long-run relationship between variables.

Findings, after the broad and meticulous inspection, concluded that liquidity and working capital perform a very important role in improving profitability in the long run. The novelty of this current study is provided guidelines for managers of the corporate world, who are involving in managing working capital activities. Moreover, findings are worthwhile for academia to focus on and understand the efficiency and effectiveness of the liquidity and working capital issues in the company. Stakeholders of the company are also interested in the proper operational activities of their corporations to maintain good yearly performances. These are operating activities that can prolong corporate success. Working capital affects profitability and this can cause to improve the wealth of shareholders. In other words, properly managed liquidity and working capital are the reason for improving the value of the firm and the worth of shareholders. 
DOI: 10.14807/ijmp.v12i1.1305

This research focused on a variety of sectors of Pakistan, where working capital and profitability are positively related in the long-run equilibrium and some sectors are negatively related in the long-run equilibrium. It depends on the sector's operational activates. This research, however, neglected all the previous researches in Pakistan that directly claimed that liquidity and profitability can be traded off of each other. In this study, eight major sectors of Pakistan, where situations according to the findings are comparatively different from each other.

However, despite being very careful with all the concerned aspects of research. It always likely to have gaps and fissures; however, these gaps could serve as foundations for further research in this area. It is recommended that in the future, new researchers could work on liquidity and profitably sector-wise and prove their findings based on unit root test, Penal integration, vector analysis, and granger causality test and avoid OLS. Findings suggested that OLS in Pakistan can never predict the correct response because data has a trend. The grounds for further research should be based on this research paper to develop sector-wise theories for the betterment of liquidity, working capital and profitability.

\section{REFERENCES}

Banos-Caballero, S., Garcia-Teruel, P. J. \& Martinez-Solano, P. (2012). How does working capital management affect the profitability of Spanish SMEs?, Small Business Economics, 39(2), 517-529.

Deloof, M. (2003). Does Working Capital Management Affect Profitability of Belgian Firms? Journal of Business Finance \& Accounting, 30(3/4), 573-587.

Eljelly, A. (2004). Liquidity-Profitability Tradeoff: An empirical Investigation in An Emerging Market, International Journal of Commerce \& Management, 14(2), 48 - 61

Edem, D. B. (2017). Liquidity management and performance of deposit money banks in Nigeria (1986- 2011): An investigation. International Journal of Economics, Finance and Management Sciences, 5(3), 146-161.

Filbeck, G., \& Krueger, T. M. (2005). An analysis of working capital management results across industries. Mid-American Journal of Business, 20(2), 10-17.

Falope, O. I., \& Ajilore, O. T. (2009). Working capital management and corporate profitability: evidence from panel data analysis of selected quoted companies in Nigeria. Research journal of business management, 3(3), 73-84.

Gill, A., Biger, N. \& Mathur, N. (2010). The relationship between working capital management and profitability: Evidence from the United States, Business and Economics Journal, vol. 10, no. 1, pp. 1-9.

Howorth, C., \& Westhead, P. (2003). The focus of working capital management in UK small firms. Management Accounting Research, 14, 94-111.

Horne Van, J. C., \& Wachowicz Jr, J. M. (2000). Fundamentals of Financial Management. 
Van Horne, J. C., \& Wachowicz, J. M. (2008). Fundamentals of financial management. Pearson Education.

Juan Garcia-Teruel, P. \& Martinez-Solano, P. (2007). Effects of working capital management on SME profitability, International Journal of managerial finance, 3(2), 164-177.

Igbekoyi, O. E. (2017). Causal effect of corporate social responsibility on value drivers in the Nigerian manufacturing sector. Journal of Emerging Trends in Economics and Management Sciences, 8(3), 169-177.

Lamberson, M. (1995). Changes in working capital of small firms in relation to changes in conomic activity. Mid-American Journal of Business, 10(2).

Lazaridis, I., \& Tryfonidis, D. (2006). Relationship between Working Capital Management and Profitability of Listed Companies in the Athens Stock Exchange. Journal of Financial Management and Analysis, 19(1), 26-35.

Lyroudi, K., \& Lazaridis, Y. (2000). The Cash Conversion Cycle and Liquidity Analysis of the Food Industry in Greece [Electronic Version]. EFMA 2000 Athens, from http://ssrn.com/paper=236175

Moyer, R. C., Mcguigan, J. R., \& Kretlow, W. J. (2003). Contemporary Financial Management (Ninth ed.). United States of America: Thomson.

Mathuva, D. M. (2010). The Relationship between working capital management and profitability for companies listed on the Nairobi Stock Exchange (Doctoral dissertation, Strathmore University).

Nobanee, H., \& Al Hajjar, M. (2009). A note on working capital management and corporate profitability of Japanese firms. Available at SSRN 1433243.

Nazir, M. S., \& Afza, T. (2009). Working capital requirements and the determining factors in Pakistan. IUP Journal of Applied Finance, 15(4), 28.

Shin, H. H., \& Soenen, L. (1998). Efficiency of working capital management and corporate profitability. Financial Practice and Education, 8(2), 37-45.

Raheman, A. \& Nasr, M. (2007) Working capital management and profitability - case of Pakistani firms. International Review of Business Research Papers, 3(1), 279-300.

Samiloglu, F., \& Akgün, A. İ. (2016). The relationship between working capital management and profitability: Evidence from Turkey. Business and Economics Research Journal, 7(2),

Samiloglu, F., \& Demirgunes, K. (2008). The effect of working capital management on firm profitability: Evidence from Turkey. The International journal of applied Economics and Finance, 2(1), 44-50.

Sanger, J. S. (2001). Working capital: a modern approach. Financial Executive, 69.

Smith, K. V. (1980). Profitability and liquidity trade off in working capital management. In Reading on the Management of Working capital (549-562). St. Paul: West Publihing Co.

Solawu, R. O. (2006). Industry Practice and Aggressive Conservative Working Capital Policies in Nigeria. European Journal of Scientific Research, 13(3).

Weinraub, H. J. \& Visscher, S. (1998). Industry practice relating to aggressive conservative working capital policies. Journal of Financial and Strategic Decisions, 11(2). 
DOI: 10.14807/ijmp.v12i1.1305

Padachi, K. (2006). Trends in working capital management and its impact on firms' performance: an analysis of Mauritian small manufacturing firms. International Review of Business Research Papers, 2(2), 45-58.

Peel, M. L. \& Wilson, N.(1996). Working capital and financial management practises in small firm sector. International Small and Business Journal, 14(2), 52-68.

Sagan, J. (1955). Toward a theory of working capital management. The Journal of Finance, 10(2), 121-129.

Shapiro, A. C., \& Hanouna, P. (2019). Multinational financial management. Wiley.

Zariyawati, M. A., Annuar, M. N., Taufiq, H., \& Rahim, A. A. (2009). Working capital management and corporate performance: Case of Malaysia. Journal of Modern Accounting and Auditing, 5(11), 47. 